\title{
Salvage of urea-nitrogen and protein requirements
}

\author{
BY ALAN A. JACKSON \\ Institute of Human Nutrition, University of Southampton, Bassett Crescent East, \\ Southampton SO16 7PX
}

The metabolism of $\mathrm{N}$ in the colon is dominated in quantitative terms by the metabolic activity of the microflora. The microflora are not found exclusively in the colon, as there are increasing numbers in the terminal ileum towards the ileocaecal valve; however, the working approximation is that functionally significant activity is colonic. There is a complex, and as yet inadequately defined, interaction of the luminal, mucosal and intramucosal populations of bacteria which is almost certainly of functional relevance. As for all organisms, the metabolic profile of the microflora is determined by the availability of substrate, which gives rise to an interdependence of protein, amino acid and $\mathrm{N}$ metabolism with the availability of energy; but for the practical purposes of the present analysis the reasonable assumption has been made that for all the work quoted, energy and other nutrients are not limiting.

In general bacteria utilize $\mathrm{NH}_{3}$ as their preferred source of $\mathrm{N}$, and other forms of protein or amino acids are reduced to $\mathrm{NH}_{3}$ before being used metabolically. The microflora represent a complex ecosystem, with aspects of a continuous-flow culture. Our knowledge of the details of this system in vivo are limited and, in particular, we are not clear of the extent to which the dwell time in the caecum and ascending colon justifies consideration of this section of the bowel as a fermentative vat, compared with the role for water and electrolyte extraction in the more distal regions (Stevens, 1988). The objective here is to identify the extent to which the hydrolysis of urea by the microflora provides $\mathrm{N}$ to the host in a form which enables the host's requirements for amino acids to be satisfied under any circumstance. Of necessity this leads to consideration of the concept of requirements itself.

\section{NITROGEN FOR THE MICROFLORA}

The potential sources of $\mathrm{N}$ available to the microflora comprise material which passes through the iloecaecal valve (both dietary residue and endogenous secretions), endogenous secretions which derive from the colon itself, and the endproducts which emanate from the metabolic activity of colonic microflora (Wrong, 1988). The flow of $\mathrm{N}$ through the ileocaecal valve is estimated to be about $2-4 \mathrm{~g} \mathrm{~N} / \mathrm{d}$ with faecal $\mathrm{N}$ being about 1-2 $\mathrm{g} \mathrm{N} / \mathrm{d}$. Therefore, the balance across the colon indicates a small net uptake. $\mathrm{N}$ derived from systemic urea contributes to faecal $\mathrm{N}$; however, only about $10 \%$ of the total faecal $\mathrm{N}$ could be ascribed to urea derived from plasma (Wrong et al. $1985 ; 200 \mathrm{mg} \mathrm{N} / \mathrm{d}$ ). These values contrast with the data derived from studies in which urea kinetics have been measured. The evidence shows that on a regular basis a proportion of the urea produced is hydrolysed by the microflora of the lower gut (Hibbert \& Jackson, 1992). In a normal adult, consuming a habitual Western diet containing $75 \mathrm{~g}$ protein/d $(12 \mathrm{~g} \mathrm{~N} / \mathrm{d})$, about $25 \%$ of urea production is salvaged (Jackson et al. 1993). This amounts to the movement of $3600 \mathrm{mg} \mathrm{N} / \mathrm{d}$ through the colon, of which about $10 \%$ is lost in the stool, $26 \%(936 \mathrm{mg}$ 


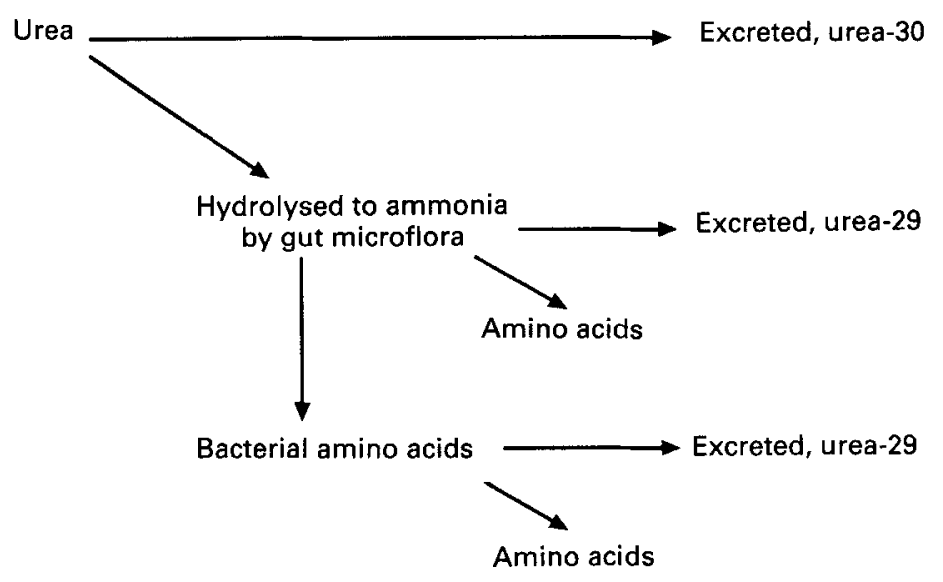

Fig. 1. The major fate of label from $\left[{ }^{15} \mathrm{~N}^{15} \mathrm{~N}\right]$ urea (urea-30) during kinetic studies. Other losses of label are relatively small, and label not recovered in urinary urea is presumed to have been retained in amino acids formed either in the liver or by the colonic microflora. Urea- $29,\left[{ }^{15} \mathrm{~N}^{14} \mathrm{~N}\right]$ urea.

$\mathrm{N} / \mathrm{d})$ returns to urea formation and the remainder $(2.3 \mathrm{~g} \mathrm{~N} / \mathrm{g}, 14.4 \mathrm{~g}$ protein $)$ is retained within the body. If urea- $\mathrm{N}$ is only $10-15 \%$ of faecal $\mathrm{N}$, then by implication the flow of $\mathrm{N}$ through the colon is about five to seven times the flow of urea-N, i.e. about $16 \mathrm{~g} \mathrm{~N} / \mathrm{d}$, or $100 \mathrm{~g}$ protein, as has been found by direct measurement (Jackson et al. 1984). Therefore, that flux of $\mathrm{N}$ through the colon which is not accounted for by the flow through the ileocaecal valve, is of the same order as the dietary intake of protein. The nature and form of this overall movement has not been elucidated. Isotopically-labelled urea has been used to trace the metabolic fate of urea-N and Fig. 1 shows the potential fate of the label. Label is lost from the body in quantitatively significant amounts either directly as urea in the urine or following metabolic interconversions in the tissues as urea (Jackson et al. 1984). $\mathrm{N}$ might be retained either by the fixation in the liver of bacterially-derived $\mathrm{NH}_{3}$, or as bacterially-derived amino acids absorbed across the gut. Thus, urea- $\mathrm{N}$ retained in the body might in principle enter metabolism, fixed as amino acids, in one of four ways (Jackson, 1982):

(1) absorbed as $\mathrm{NH}_{3}$ and fixed in the liver through amination of the non-essential amino acids, i.e. as glutamate or glycine-serine,

(2) through wider transamination with the $\mathrm{C}$ skeleton of transaminating non-essential amino acids, i.e. alanine and aspartate,

(3) through wider transamination with the $\mathrm{C}$ skeleton of transaminating essential amino acids,

(4) by bacterial fixation as essential and non-essential amino acids which are then available to the host through absorption.

In adults, on an intake of about $70 \mathrm{~g}$ protein/d, when $\mathrm{NH}_{3}$ is given orally, label is predominantly incorporated into urea, but there is also ready exchange with glutamate and through serine-glycine interaction (Jackson \& Golden, 1981; Nissim et al. 1981). On lower protein intakes, or when the label is given intravenously, the rate of incorporation into proteins is greatly increased (Furst et al. 1969, 1970). The movement of label around other amino acids is directly related to their ability to engage in $\mathrm{N}$-exchange reactions, 
which is variable, and strictly limited for the essential (indispensable) amino acids (Aqvist, 1951). Amino acids fulfil metabolic roles other than as constituents of proteins, and some of these metabolic pathways may represent a significant drain on the available substrate, especially for non-essential (dispensable) amino acids and N. For example, glycine acts as the precursor for a range of metabolic intermediates, each of which represents an endproduct with no return of glycine to the metabolic pool (Jackson, 1991). Thus, the daily formation of creatine which is eventually lost as creatinine in the urine, consumes $196 \mathrm{mg} \mathrm{N}$ as glycine/d and $392 \mathrm{mg} \mathrm{N}$ as arginine/d. The formation of haem requires a further $38 \mathrm{mg} \mathrm{N}$ as glycine/d (Reeds, 1988). The total, about $626 \mathrm{mg}$ $\mathrm{N} / \mathrm{d}$, is nearly half the salvaged urea- $\mathrm{N}$ which is retained in the body pool each day. Thus, the need for the formation of substantial amounts of non-essential amino acids is clear and there is little difficulty in seeing that urea- $\mathrm{N}$ might contribute to the satisfaction of these needs. The greater problem is whether bacterially-derived essential amino acids are available to the host, and if so, in what amounts. This will now be considered in greater detail.

One point which is clear is that the metabolic activity of urea- $N$ can only usefully be considered in the context of the overall metabolic state of the body as a whole. The factors which determine the rate of salvage have been outlined elsewhere, but in general can be characterized as being determined by the balance between the metabolic demand for amino acids and the dietary intake of protein (Jackson, 1993). For a fixed demand salvage increases as intake falls; for a fixed intake salvage increases as demand increases (Jackson \& Wootton, 1990). In other words salvage is a function of the metabolic requirement for amino acids, which is often loosely articulated as the requirement for protein; a point which has caused considerable confusion in nutrition and its literature. There is a terminology for which the use tends to be non-systematic and which, therefore, has generated confusion. Of particular relevance is the use of the term 'requirement' to mean variously, and inconsistently, the dietary requirement, the metabolic requirement, the dietary and/or metabolic requirement for protein, amino acids or $\mathrm{N}$.

\section{OLDER CONCEPTS OF REQUIREMENTS}

The term 'requirements' has been used most extensively in human metabolism for the determination of recommended dietary allowance for energy and nutrients for the population (Food and Agriculture Organization/World Health Organization/United Nations University (FAO/WHO/UNU), 1985). For many years it was characterized as that amount required in the diet to maintain $\mathrm{N}$ equilibrium in normal adults. In this sense, there is a conceptual link to the ideas of: obligatory $\mathrm{N}$ loss, the first limiting amino acid and protein quality, amino acids being classified as either essential (indispensable) or non-essential (dispensable).

The dietary requirement for protein was that amount which needed to be taken in the diet in order to maintain $\mathrm{N}$ equilibrium. It was clearly recognized that the requirement was influenced by the intake of energy and other nutrients. However, on the assumption that the intake of energy and other nutrients was adequate, it was possible to define with some reliability the requirements for protein, amino acids and $\mathrm{N}$ from one situation to another by the use of the N-balance technique. A considerable body of data was collected using this approach during the 1960s and into the early 1970s. In particular, the 


\begin{tabular}{|cc|}
\hline Rank order for $N$ intake & Rank order for non-essential N \\
EAA, $2 \times$ minimum, with NEAA & Non-essential amino acids \\
EAA, minimum, NEAA & Glycine and glutamate \\
EAA, minimum, NEN & Glycine and DAC \\
& Glycine and urea \\
& DAC \\
& Urea \\
\hline
\end{tabular}

Fig. 2. The dietary requirement for amino acids is determined by the pattern of amino acids required for protein synthesis and other pathways. The relative efficiency with which this demand can be satisfied is determined by the pattern of amino acids and $\mathrm{N}$ in the diet. The more metabolic exchange of $\mathrm{N}$ to achieve a pattern of amino acids which matches the demand, the higher the total $\mathrm{N}$ intake required to achieve $\mathrm{N}$ balance. EAA, essential amino acids; NEAA, non-essential amino acids; DAC, diammonium citrate; NEN, nonessential $\mathrm{N}$.

classic series of studies carried out by Kies and her coworkers (Kies, 1972) provide a very clear picture of the inter-relationships amongst the amount of protein in the diet, the pattern of amino acids in the diet and the amount of $\mathrm{N}$ required to achieve $\mathrm{N}$ balance in normal men and women. From the data generated by this work, recognizing the circumstances under which the studies were carried out, it is possible to draw conclusions of a general nature. For any given pattern of intake, the greater the amount of $\mathrm{N}$ exchange involved, the higher the level of total $\mathrm{N}$ required to achieve balance. In other words, on the assumption that there is a metabolic demand for a defined pattern of amino acids, the closer the pattern of amino acids in the diet to the pattern of demand the less the total amount of amino acids needed for balance. In this context it may be that the essential amino acids simply represent a special case of a more general rule. Using the data derived from this series of balance studies it is possible to characterize the relative efficiency of utilization of different sources of amino acids and $\mathrm{N}$ in diets, as shown in Fig. 2. $N$ equilibrium can be achieved at the lowest level of total $N$ intake, about $3-4 \mathrm{~g} / \mathrm{d}$, when the diet comprises amino acids at two to three times the minimal requirements as determined by Rose (1957) and a mixture of non-essential amino acids is provided at relatively low levels. It is clear that a number of non-essential amino acids can substitute for essential amino acids and balance can be achieved with Rose's (1957) minimal requirements and a total $\mathrm{N}$ intake of about $6-8 \mathrm{~g} / \mathrm{d}$. Further, non-essential $\mathrm{N}$ can substitute for non-essential amino acids and, although balance can be achieved readily with Rose's (1957) minimal requirements for essential amino acids, the total $\mathrm{N}$ intake might need to be increased to $12 \mathrm{~g} / \mathrm{d}$. The relative effectiveness of substitutions with different forms of non-essential $\mathrm{N}$ vary in the order shown in Fig. 2 . The data inevitably tend to suggest that it is possible for essential amino acids to be formed endogenously, albeit at low levels and relatively inefficiently. Although at that time there was little direct evidence to justify this conclusion, the first human data were becoming available (Giordano et al. 1968), and were used by Kies as a possible explanation of the phenomenon in her later papers (Korslund et al. 1977; Kies \& Fox, 1978). 


\section{MORE RECENT IDENTIFICATION OF REQUIREMENTS}

For a number of reasons the $\mathrm{N}$-balance technique has limitations and it fell into disrepute as an investigative tool (Hegsted, 1976). There appeared to be some inconsistency in the results obtained and the underlying reasons for the inconsistencies could not be determined without a finer appreciation of the metabolic processes through which balance was achieved in response to dietary change (Waterlow, 1968). The availability of dynamic measures of amino acid and $\mathrm{N}$ metabolism opened the possibility of exploring other approaches to determining the requirements for nutrients which are essential dietary constituents (Waterlow, 1968; Waterlow \& Stephen, 1981). Around the same time the FAO/WHO/UNU (1985) Joint Expert Consultation on Protein and Energy Requirements was reaching the conclusion that in policy terms the food problems of the world related more obviously to issues surrounding the satisfaction of energy requirements. The implication of this shift in emphasis was that there was no obvious problem for protein which would not be addressed once the problem of total food intake had been resolved (Waterlow \& Payne, 1975). Further, given the difficulty of measuring habitual food intake with sufficient precision, it was concluded that it would be desirable to use measurements of expenditure as the basis for determining the requirements for energy (FAO/WHO/UNU, 1985).

These two ideas have come together in much of the approach which has been developed since that time for the exploration of protein and amino acid metabolism. The general approach also owes something to the classical perception that the determination of obligatory $\mathrm{N}$ losses can inform us of the general nature of protein requirements. From this point it is a short step to presuming that if the rate of oxidation of an essential amino acid is measured in the fed and fasting state, then this will provide information on the dietary requirement for that amino acid (Young et al. 1989). The logic for this approach is impeccable and internally consistent. Therefore, the newer approaches to characterizing the dynamic state of the body constituents, have derived great momentum from the approaches which have been used to measure whole-body protein turnover, which in turn has led to more refined methods for measuring aspects of amino acid kinetics.

The general model which is used for the determination of amino acid kinetics and whole-body protein turnover is shown in Fig. 3. For any amino acid the flux through the amino acid pool comprises three inflows (dietary intake, protein degradation and de novo formation) and three outflows (oxidation, protein synthesis and other metabolic pathways). In practice, two measurements are made: the rate of appearance of the amino acid in the pool, based on the dilution of an infused label of the amino acid, and the rate of oxidation of the amino acid, based on the rate of appearance of labelled $\mathrm{CO}_{2}$ from the amino acid in breath. $\left[{ }^{13} \mathrm{C}\right]$ Leucine has been used most extensively for this work. For most studies with essential amino acids, one inflow (de novo formation) is presumed to be zero and one outflow (other metabolic pathways) is presumed to be small enough to be ignored. By making a number of assumptions it is possible to derive other relationships from these data, including rates of whole-body protein synthesis and degradation.

Elegant studies of this kind have led Young and his colleagues (Young et al. 1989; Marchini et al. 1993) to the conclusion that the requirements for essential amino acids are greater than has been determined from balance studies, and they have developed a pattern of amino acid requirements, the Massachusetts Institute of Technology (MIT) pattern, based on this approach. As can be seen from Fig. 4, which shows the MIT amino 


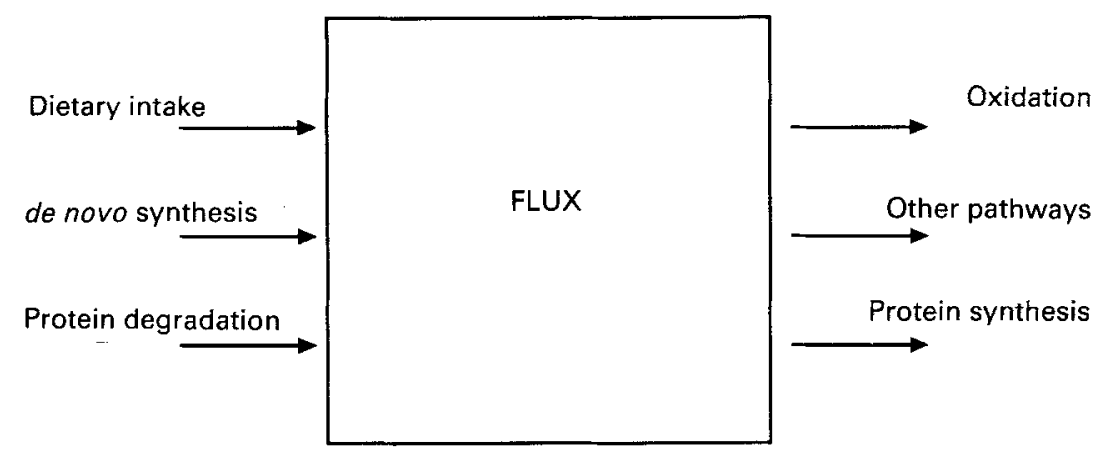

Fig. 3. The general model for the kinetics of any amino acid presumes a single pool through which the amino acid flows, with three inputs and three outputs. For essential amino acids one inflow, de novo synthesis, is presumed to be zero and for most amino acids one outflow, other pathways, is considered to be relatively small and, therefore, ignored in many analyses.

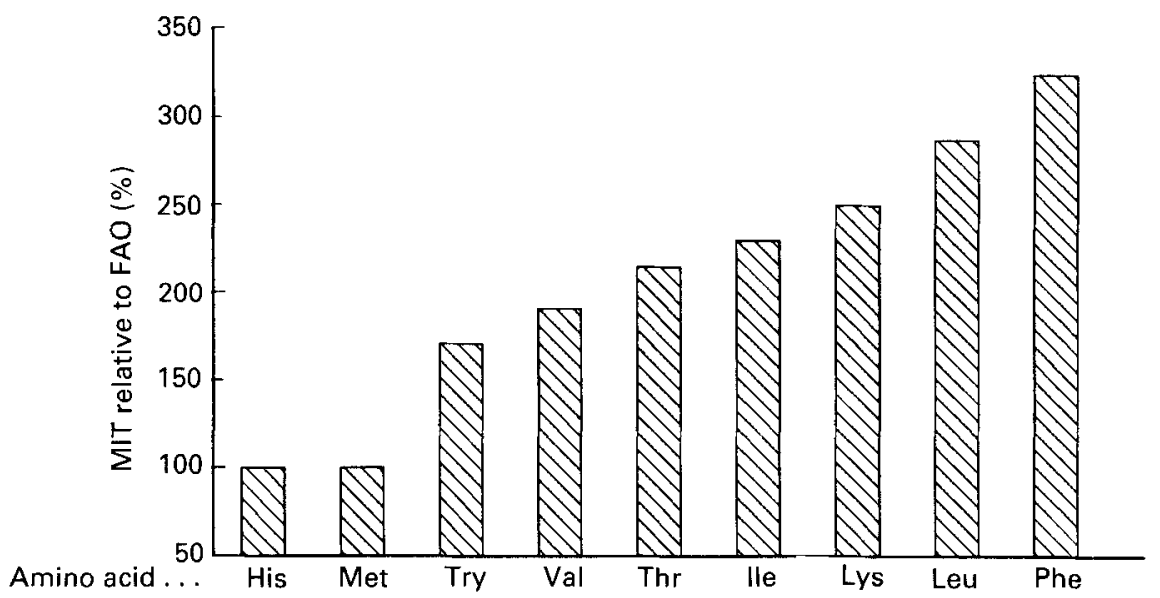

Fig. 4. A comparison of the patterns of minimal requirements of essential amino acids as recommended by Food and Agriculture Organization/World Health Organization/United Nations University (1985; FAO), based on the data of Rose (1957), and the Massachusetts Institute of Technology (MIT) pattern which has been proposed by Young et al. (1989). Values represent MIT requirements as a percentage of FAO values.

acid requirements (Young et al. 1989) as a percentage of the FAO/WHO/UNU (1985; FAO) requirements there is an increase of $181 \%$ in the requirement for the essential amino acids, varying on an individual average from $100 \%$ for methionine to $324 \%$ for phenylalanine. Therefore, since the data from classical balance studies do not conform to the data from the newer isotope studies, it is important to question the extent to which the assumptions on which the different approaches are based are sustainable. For the FAO pattern of essential amino acids, the intake for a $75 \mathrm{~kg}$ man would be equivalent to 
Table 1. Leucine kinetics were measured with $/{ }^{13}$ Clleucine in men taking crystalline amino acids, equivalent to $78 \mathrm{~g}$ protein/d, based on either the Food and Agriculture Organization/ World Health Organization/United Nations University (1985; FAO) or the Massachusetts Institute of Technology (Young et al. 1989; MIT) pattern of essential amino acids and urea kinetics in adult men measured over $24 \mathrm{~h}$ on a diet which provides $188 \mathrm{~kJ}(45 \mathrm{kcal}) / \mathrm{kg}$ per d and $1 \mathrm{~g}$ protein $/ \mathrm{kg}$ per $d$, with leucine comprising $80 \mathrm{mg} / \mathrm{kg}$ per $d$ in the diet and $9.4 \mathrm{mg} / \mathrm{kg}$ per $d$ in the infusion (El-Khouri et al. 1994)

\begin{tabular}{ccccc}
\hline & & \multicolumn{2}{c}{$\begin{array}{c}\text { Leucine oxidation } \\
(\mathrm{mg} / \mathrm{kg})\end{array}$} & \\
\cline { 3 - 4 } & $\begin{array}{c}\text { Leucine intake } \\
(\mathrm{mg} / \mathrm{kg} \text { per d })\end{array}$ & Fed, $12 \mathrm{~h}$ & Fasted, $12 \mathrm{~h}$ & $\begin{array}{c}\text { Leucine balance } \\
(\mathrm{mg} / \mathrm{kg} \text { per d })\end{array}$ \\
\cline { 3 - 4 } FAO & 14 & $12 \cdot 8$ & 15 & $-13 \cdot 4$ \\
MIT & $38 \cdot 3$ & $24 \cdot 3$ & $20 \cdot 9$ & $-6 \cdot 2$
\end{tabular}

Apparent appearance of leucine- $\mathrm{N} 0.66-1.43 \mathrm{mg} \mathrm{N} / \mathrm{kg}$ per $\mathrm{d}$

\begin{tabular}{lcccc} 
& \multicolumn{3}{c}{ Urea $(\mathrm{mg} \mathrm{N} / \mathrm{kg}$ per d) } & Salvage relative \\
\cline { 2 - 4 } & Production & Excretion & Salvage & to production $(\%)$ \\
\hline Fed & 73 & 73 & 0 & - \\
Fasted & 77 & 42 & 35 & 45 \\
Total & 150 & 115 & 35 & 23
\end{tabular}

Estimated for low-protein diet based on data of Langran et al. (1992)

Total

129

44

85

66

$0.984 \mathrm{~g} \mathrm{~N} / \mathrm{d}$, whereas for the MIT pattern it would be $1.78 \mathrm{~g} \mathrm{~N} / \mathrm{d}$, a difference of $0.796 \mathrm{~g}$ $\mathrm{N} / \mathrm{d}$ (equivalent to $5 \mathrm{~g}$ protein; Marchini et al. 1993). Table 1 shows that if leucine kinetics are compared at $14 \mathrm{mg} / \mathrm{kg}$ per d (FAO requirement) and $38.3 \mathrm{mg} / \mathrm{kg}$ per d (MIT requirement) in adult men taking the equivalent of $78 \mathrm{~g}$ protein as amino acids/d, the oxidation of leucine exceeds the intake on both diets, but the difference is larger for the FAO pattern $(-13.4 \mathrm{mg} / \mathrm{kg}$ per d) than for the MIT pattern $(-6.2 \mathrm{mg} / \mathrm{kg}$ per d; Marchini et al. 1993). If the subjects in these studies were in $\mathrm{N}$ equilibrium, this would represent an apparent appearance of leucine- $\mathrm{N}$ of 1.43 and $0.66 \mathrm{mg} \mathrm{N} / \mathrm{kg}$ per $\mathrm{d}$ respectively.

Urea kinetics have been measured in similar subjects on a diet which provided $1 \mathrm{~g}$ protein $/ \mathrm{kg}$ per $\mathrm{d}$ and $188 \mathrm{~kJ}(45 \mathrm{kcal}) / \mathrm{kg}$ per $\mathrm{d}$ and contained leucine at $80 \mathrm{mg} / \mathrm{kg}$ per d and an infusion of a further $9.4 \mathrm{mg} / \mathrm{kg}$ (El-Khouri et al. 1994). In common with other studies they found that over a $24 \mathrm{~h}$ period $25 \%$ of the urea- $\mathrm{N}$ produced was salvaged, which was about $2.6 \mathrm{~g} \mathrm{~N} / \mathrm{d}$ for a $75 \mathrm{~kg}$ man. In our experience, a conservative estimate would suggest that at least half this $\mathrm{N}$ would be retained within the metabolic pool, $1.3 \mathrm{~g}$ $\mathrm{N} / \mathrm{d}$ (Jackson et al. 1993). On a diet which provides only $35 \mathrm{~g}$ protein/d (about $0.5 \mathrm{~g}$ protein $/ \mathrm{kg}$ per d), urea production would be expected to fall by about $15 \%$, and salvage would increase to $66 \%$ of production (Langran et al. 1992). On the assumption that half the salvaged $\mathrm{N}$ was incorporated as metabolic $\mathrm{N}$, the salvaged urea- $\mathrm{N}$ would provide $3.2 \mathrm{~g} \mathrm{~N} / \mathrm{d}$ for a $75 \mathrm{~kg}$ man.

The justification for presuming that this $\mathrm{N}$ might be available as bacterially-derived 
essential amino acids is presented. If the assumption is made that leucine comprises $5 \%$ of the residues in bacterial protein it can be calculated that the provision of bacteriallyderived leucine would be about 8 or $20 \mathrm{mg} / \mathrm{kg}$ per d for diets which provided 75 or $35 \mathrm{~g}$ protein/d respectively. These values are well within the differences obtained for overall leucine balance obtained in the study where either the FAO or the MIT patterns of leucine intake were determined (Marchini et al. 1993). Therefore, the question of whether it can be assumed that there is no endogenous formation of the essential amino acids becomes of very great importance. Further, the data presented by El-Khouri et al. (1994) show that the rate of leucine oxidation changes relatively little between the fed and the fasted states and, as would be expected therefore, the rate of urea formation also changes little between the fed and fasted states. In marked contrast, the rate of urea excretion is substantially greater in the fed state than that in the fasted state. Thus, there is evidence for a diurnal cycle of urea salvage, being virtually zero during the fed state with $50 \%$ of production found during the fasted state, appropriately meeting the demand for leucine in the face of sporadic dietary intake. The wider implications of these observations for validity of the model which many have used for determining protein kinetics are considerable. Clearly if the de novo formation of essential amino acids does take place, then it cannot be assumed that the only inflows to the leucine pool are from the dietary intake and protein degradation. Under these circumstances it is not possible to derive a reliable value for protein degradation.

\section{Evidence for bacterial essential amino acids}

It is well established in ruminant nutrition that the metabolic activity of the microflora of the foregut plays a critical role in the conversion of simple sources of $\mathrm{N}$ to amino acids which are directly available to the host (Briggs, 1967). The extent to which a similar relationship might exist for hindgut fermentation in all species has been less clear. Part of the reason for the lack of clarity has been the physical inaccessibility in practice of the hepatic portal vein and the caecum and proximal colon, where much of the fermentative activity is thought to take place. Also, in the studies which have been carried out, the work has often been at the limits of the available technology. Furthermore, animal experiments have always been a poor substitute for human investigation in this area. In small rodents bacterial protein will present itself for digestion and absorption through refection and in larger animals, such as the pig, the florid microflora in the small bowel makes interpretation difficult.

Human studies are dependent on the use of isotopic tracers and the first direct evidence of incorporation of urea- $\mathrm{N}$ into amino acids was reported by Giordano $e t$ al. (1968). They fed $\left[{ }^{15} \mathrm{~N}\right]$ urea for $4-6 \mathrm{~d}$ to one normal subject and to patients with renal failure on diets which provided as little as $1.68 \mathrm{~g} \mathrm{~N} / \mathrm{d}$. The relative enrichment of ${ }^{15} \mathrm{~N}$ from urea into amino acids was measured in amino acids isolated from plasma albumin at $6 \mathrm{~d}$. Variable amounts of label were recovered in both the non-essential and the essential amino acids (Fig. 5). Although the levels of enrichment were much greater in the transaminating non-essential amino acids (e.g. glutamate, alanine), significant recovery was obtained in the essential amino acids (e.g. leucine, lysine). For both groups of amino acids the enrichment was increased about threefold on a low protein intake, and this effect was substantially reduced after antibiotics had been taken to eradicate the colonic bacteria. In the discussion of the paper, comment is made that following the adminis- 


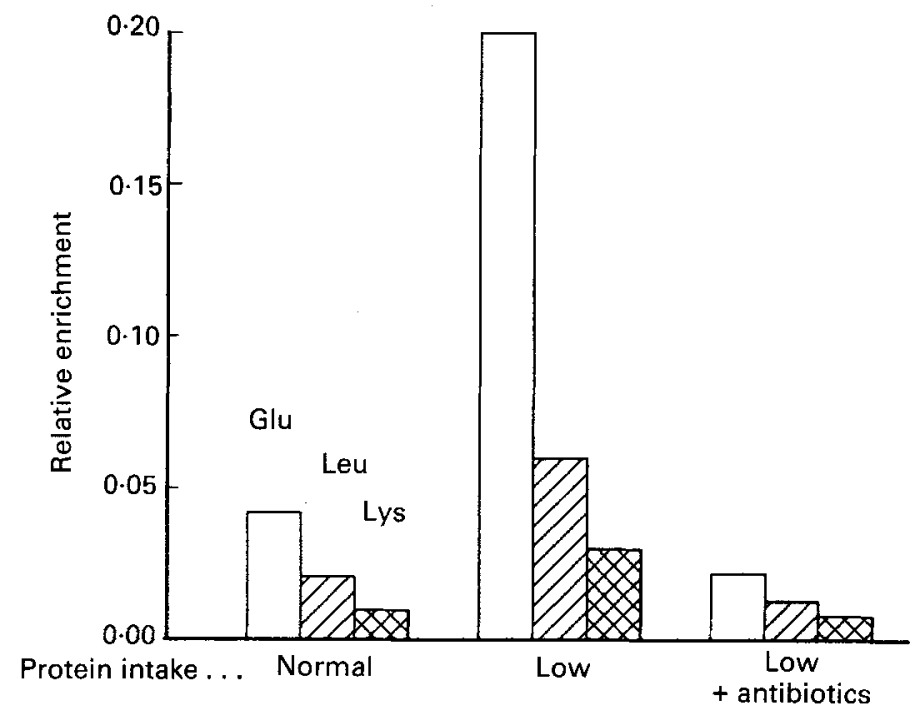

Fig. 5. Following oral $\left[{ }^{15} \mathrm{~N}^{15} \mathrm{~N}\right]$ urea for $6 \mathrm{~d}$, the enrichment in amino acids isolated from plasma albumin was determined for a normal subject and for renal patients on a low-protein diet, with and without antibiotics to sterilize the colon. (From Giordano et al. 1969).

tration of $\left[{ }^{14} \mathrm{C}\right]$ glucose, label was incorporated into constituent amino acids of albumin which overlapped with the incorporation of ${ }^{15} \mathrm{~N}$, implying that the essential $\mathrm{C}$ skeleton had been formed endogenously rather than there simply being transamination. The results are similar to the Japanese studies which show incorporation of ${ }^{15} \mathrm{~N}$ from urea into amino acids in Papua New Guinea Highlanders on their habitual low-protein diet, or Japanese on low-protein diets (Tanaka et al. 1980). Rat studies, also, have shown that incorporation of ${ }^{15} \mathrm{~N}$ label from urea into non-essential amino acids and essential amino acids, including lysine, was increased on a low-protein diet and abolished after treatment with antibiotics (Tanaka, 1982). More recently, Torrallardona et al. (1993a,b) have demonstrated the movement of ${ }^{15} \mathrm{~N}$ and ${ }^{14} \mathrm{C}$ into lysine in the pig and the rat when the only dietary source of $\mathrm{N}$ was $\mathrm{NH}_{3}$. Labelling of lysine was not seen in gnotobiotic rats. In a repeat of the earlier studies by Kies \& Fox (1977) it has been found that the addition of large amounts of urea- $\mathrm{N}, 6.4 \mathrm{~g}$, to a diet which provides $4.8 \mathrm{~g}$ protein-N/d, enhances the salvage of urea- $\mathrm{N}$ and reduces the negative $\mathrm{N}$ balance towards equilibrium (Meakins \& Jackson, 1995). We have recently found that in children who have been severely malnourished, $\mathrm{N}$ from labelled urea can be recovered in urinary lysine in amounts that are probably of functional significance (Fig. 6).

Together, the data make it quite clear that qualitatively there is formation of essential as well as non-essential amino acids by the colonic microflora, which are available to the host. The only uncertainty is whether the amounts are of functional relevance. The evidence would suggest that the endogenous formation of essential amino acids might amount to about one to two times Rose's (1957) minimum requirements for essential amino acids, under suitable circumstances, but it is still early to be conclusive on this point.

Therefore, the data in the literature are coherent and the contradictions are more 


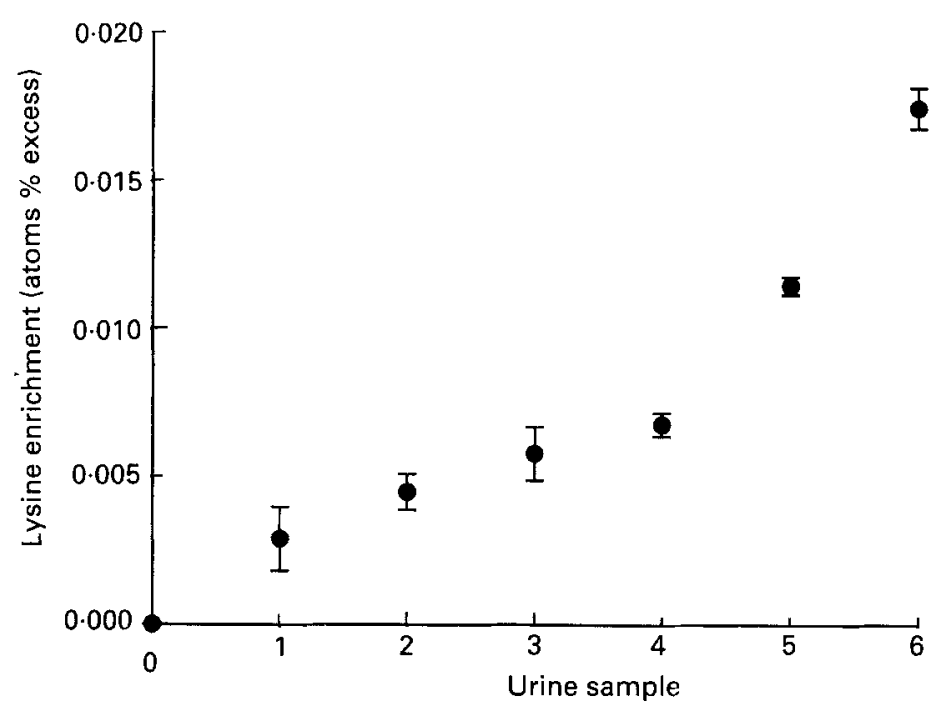

Fig. 6. In a child who had been treated for severe malnutrition, the enrichment of lysine isolated from urine was measured, following prime and intermittent oral doses of $\left[{ }^{15} \mathrm{~N}^{15} \mathrm{~N}\right] \mathrm{urea}$. An oral priming dose of isotope was given to reduce the time taken to achieve an isotopic plateau in urea in the urine. This was followed by hourly intermittent oral doses of isotope. Points are means with their standard errors represented by vertical bars for four analyses. (From D. J. Millward, T. E. Forrester \& A. A. Jackson, unpublished results).

apparent than real if one allows that the assumptions on which the models have been based are open to modification. Of particular importance in this respect are:

(1) the incorrect assumption of ready and free movement of $\mathrm{N}$ by transamination,

(2) the incorrect assumption that the salvage of urea- $\mathrm{N}$ has no functional relevance,

(3) the incorrect assumption that essential amino acids cannot be formed endogenously,

(4) the failure to differentiate adequately amongst protein, amino acids and $\mathrm{N}$ in the diet and intermediary metabolism.

\section{PROPOSED OUTLINE FOR CONSIDERING PROTEIN, AMINO ACID AND NITROGEN REQUIREMENTS}

I would propose, therefore, a general characterization of requirements which does not presume anything beyond what can be identified with confidence.

The physiological requirement for an amino acid is determined by the functional metabolic demand to satisfy the needs for protein synthesis and other metabolic pathways. Hence, the physiological or metabolic requirement is the sum total of the amino acids needed to satisfy this demand. The demand is determined by the overall metabolic and physiological state of the individual at that point in time. The physiological requirement may be satisfied either from endogenous formation, or from the diet and:

$$
\text { physiological requirement }=\text { endogenous formation }+ \text { dietary requirement. }
$$


The dietary requirement for an amino acid is determined by the extent to which endogenous formation of the amino acid satisfies the physiological requirement.

The dietary requirement for protein is the amount of protein which will satisfy the dietary requirement for the first limiting amino acid.

The requirement for $\mathrm{N}$ is the effective availability of $\mathrm{N}$ for a given protein intake to enable the endogenous formation of amino acids to satisfy the physiological requirement. This will include all forms of $\mathrm{N}$ in the diet and that $\mathrm{N}$ available through the salvage of urea-N.

The extent to which any particular amino acid may be formed endogenously is not known. However, by convention it has come to be accepted that the essential amino acids are either not formed endogenously, or only to a very limited extent, whilst the non-essential amino acids are readily formed endogenously with a substantial reserve capacity. Increasingly it appears likely that there may be some capacity to form essential amino acids endogenously, and that there is an upper limit to the capacity to form non-essential amino acids endogenously. Therefore, there is the need to explore the limits of endogenous formation and the conditions under which these might vary for all amino acids and to relate this to the changing metabolic demand encountered as the organism moves from one state to another.

\section{OUTSTANDING ISSUES}

There are a number of outstanding issues which will need more detailed consideration when sufficient evidence is available. First, the extent to which there is a metabolic benefit associated with the oxidation of amino acids is not clear. This issue may be related to the anabolic drive described by Millward (1992). Second, there are situations, such as in the fetus, where amino acid oxidation appears to be central to energy homeostasis (Jackson, 1994), and the extent to which amino acids might be required to provide gluconeogenic substrate is not clear. Third, the quantitative roles of amino acids in pathways such as $\mathrm{C}_{1}$ transfer, $\mathrm{S}$ metabolism, choline and carnitine metabolism need to be determined. Finally, and perhaps of fundamental importance, is the need to measure the limit for the de novo formation of each amino acid under standard conditions.

\section{REFER்ENCES}

Aqvist, S. E. G. (1951). Metabolic relationships among amino acids studied with isotopic nitrogen. Acta Chemica Scandinavica 5, 1046-1064.

Briggs, M. H. (1967). Urea as a Protein Supplement. London: Pergamon Press.

El-Khouri, A. E., Fukagawa, N. K., Sanchez, M., Tsay, R. H., Gleason, R. E., Chapman, T. E. \& Young, V. R. (1994). Validation of the tracer balance concept with reference to leucine: $24-\mathrm{h}$ intravenous tracer studies with L- $[1-13 \mathrm{C}]$ leucine and $\left[{ }^{15} \mathrm{~N}^{15} \mathrm{~N}\right]$ urea. American Journal of Clinical Nutrition 59, 1000-1011.

Food and Agriculture Organization/World Health Organization/United Nations University (1985). Energy and Protein Requirements. Report of a Joint Expert Consultation. Technical Report Series no. 724. Geneva: WHO.

Furst, P., Jonsson, A., Josephson, B. \& Vinnars, E. (1970). Distribution in muscle and liver vein protein of ${ }^{15} \mathrm{~N}$ administered as ammonium acetate to man. Journal of Applied Physiology 29, 307-312.

Furst, P., Josephson, B., Maschio, G. \& Vinnars, E. (1969). Nitrogen balance after intravenous and oral administration of ammonium salts to man. Journal of Applied Physiology 26, 13-22.

Giordano, C., de Pascale, C., Baliestrieri, C., Cittadini, D. \& Crescenzi, A. (1968). Incorporation of urea ${ }^{15} \mathrm{~N}$ in amino acids of patients with chronic renal failure on low nitrogen diet. American Journal of Clinical Nutrition 21, 394-404. 
Hegsted, D. M. (1976). Balance studies. Journal of Nutrition 106, 307-311.

Hibbert, J. M. \& Jackson, A. A. (1991). Variation in measures of urea kinetics over four years in a single adult. European Journal of Clinical Nutrition 45, 347-351.

Jackson, A. A. (1982). Amino acids: essential and non-essential? Lancet i, 1034-1037.

Jackson, A. A. (1991). The glycine story. European Journal of Clinical Nutrition 45, 59-65.

Jackson, A. A. (1993). Chronic malnutrition: protein metabolism. Proceedings of the Nutrition Society 52, $1-10$.

Jackson, A. A. (1994). Urea as a nutrient: bioavailability and role in nitrogen economy. Archives of Disease in Childhood 70, 3-4.

Jackson, A. A., Danielsen, M. S. \& Boyes, S. (1993). A non-invasive method for measuring urea kinetics with a single dose of $\left[{ }^{15} \mathrm{~N}^{15} \mathrm{~N}\right]$ urea in free-living humans. Journal of Nutrition 123, 2129-2136.

Jackson, A. A. \& Golden, M. H. N. (1981). Deamination versus transamination. In Nitrogen Metabolism in Man, pp. 203-213 [J. C. Waterlow and J. M. L. Stephen, editors]. Barking: Applied Science Publishers.

Jackson, A. A., Picou, D. \& Landman, J. (1984). The non-invasive measurement of urea kinetics in normal man by a constant infusion of ${ }^{15} \mathrm{~N}^{15} \mathrm{~N}$-urea. Human Nutrition: Clinical Nutrition 38C, 339-354.

Jackson, A. A. \& Wootton, S. A. (1990). The energy requirements of growth and catch-up growth. In Activity, Energy Expenditure and Energy Requirements of Infants and Children, pp. 185-214 [B. Schurch and N. S. Scrimshaw, editors]. Switzerland: International Dietary Energy Consultative Group.

Kies, C. (1972). Nonspecific nitrogen in the nutrition of human beings. Federation Proceedings 31, $1172-1177$.

Kies, C. \& Fox, H. M. (1978). Urea as a dietary supplement for humans. Advances in Experimental Medicine and Biology 105, 103-118.

Korslund, M. K., Kies, C. \& Fox, H. M. (1977). Protein nutrition values of urea supplementation of opaque-2 corn for adolescent boys. American Journal of Clinical Nutrition 30, 371-374.

Langran, M., Moran, B. J., Murphy, J. L. \& Jackson, A. A. (1992). Adaptation to a diet low in protein: effect of complex carbohydrate upon urea kinetics in normal man. Clinical Science 82, 191-198.

Marchini, J. S., Cortiella, J., Hiramatsu, T., Chapman, T. E. \& Young, V. R. (1993). Requirements for indispensable amino acids in adult humans: longer-term amino acid kinetic study with support for the adequacy of the Massachusetts Institute of Technology amino acid requirement pattern. American Journal of Clinical Nutrition 58, 670-683.

Meakins, T. \& Jackson, A. A. (1994). Urea appearance: critical determinant of urea-nitrogen salvage on a low-protein diet. Proceedings of the Nutrition Society 53, 196A.

Millward, D. J. (1992). The metabolic basis of amino acid requirements. In Protein-Energy Interactions, pp. 31-56 [N. S. Scrimshaw and B. Schurch, editors]. Switzerland: International Dietary Energy Consultative Group.

Nissim, I., Yudkof, F. M., Yang, W., Terwilliger, T. \& Segal, S. (1981). Gas chromatograph-mass spectrometry determination of $\left[{ }^{15} \mathrm{~N}\right]$ ammonia enrichment in blood and urine. Analytical Biochemistry 114, 125-130.

Reeds, P. J. (1988). Nitrogen metabolism and protein requirements. In Comparative Nutrition, pp. 55-72 [K. Blaxter and I. Macdonald, editors]. London: John Libbey.

Rose, W. C. (1957). The amino acid requirements of adult man. Nutrition Abstracts and Reviews 27, 631-647.

Stevens, C. E. (1988). Comparative physiology of the vertebrate digestive system. In Comparative Nutrition, pp. 21-36 [K. Blaxter and I. Macdonald, editors]. London: John Libbey.

Tanaka, N. (1982). Urea utilization in protein deficient rats. Journal of Japanese Society of Nutrition and Food Science 35, 175-180.

Tanaka, N., Kubo, K., Shiraki, K., Koishi, H. \& Yoshimura, H. (1980). A pilot study on protein metabolism in the Papua New Guinea Highlanders. Journal of Nutritionai Science and Vitaminology 26, 247-259.

Torrallardona, D., Harris, C. I., Milne, E. \& Fuller, M. F. (1993a). Contribution of intestinal microflora to lysine requirements in non-ruminants. Proceedings of the Nutrition Society 52, 153A.

Torrallardona, D., Harris, C. I., Milne, E., Ronaasen, V., Coates, M. E. \& Fuller, M. F. (1993b). Contribution of intestinal microflora to lysine requirements in rats. Proceedings of the Nutrition Society $\mathbf{5 2}$, 368A.

Waterlow, J. C. (1968). Observations on the mechanisms of adaptation to low protein intakes. Lancet ii, 1091-1097.

Waterlow, J. C. \& Payne, P. R. (1975). The protein gap. Nature 258, 113-117.

Waterlow, J. C. \& Stephen, J. M. L. (1981). Nitrogen Metabolism in Man. Barking: Applied Science Publishers. 
Wrong, O. M. (1988). Bacterial metabolism of protein and endogenous nitrogen compounds. In Role of the Gut Flora in Toxicity and Cancer, pp. 227-262 [I. R. Rowkind, editor]. New York: Academic Press.

Wrong, O. M., Vince, A. J. \& Waterlow, J. C. (1985). The contribution of endogenous urea to faecal ammonia in man, determined by ${ }^{15} \mathrm{~N}$ labelling of plasma urea. Clinical Science 68, 193-199.

Young, V. R., Bier, D. M. \& Pellet, P. L. (1989). A theoretical basis for increasing current estimates of the amino acid requirements in adult man, with experimental support. American Journal of Clinical Nutrition $\mathbf{5 0}, 80-92$. 